\title{
Polychlorinated dibenzo-p-dioxins and dibenzofurans in eggs of eight avian species from Dongting Lake, China
}

\author{
Liping Fang, Minghui Zheng *, Bing Zhang, Lirong Gao, Wenbing Liu, Xingru Zhao \\ State Key Laboratory of Environmental Chemistry and Ecotoxicology, Research Center for Eco-Environmental Sciences, \\ Chinese Academy of Sciences, P.O. Box 2871, Beijing 100085, China
}

Received 16 August 2006; received in revised form 4 April 2007; accepted 26 April 2007

Available online 19 June 2007

\begin{abstract}
Concentrations of polychlorinated dibenzo-p-dioxins (PCDDs) and dibenzofurans (PCDFs) were determined in eggs of eight avian species collected from Dongting Lake of China to assess residue levels, accumulation patterns, and toxic potential in different avian species. Concentrations of total 2,3,7,8-substituted PCDD/Fs were in the range of 10.8-182 $\mathrm{pg} \mathrm{g}^{-1}$ lipid weight. Eggs of great egret and lesser pied kingfisher contained higher levels of PCDD/Fs than eggs of other species, indicating the specific exposure and accumulation of PCDD/Fs relating to feeding habits and the life span. PCDD/Fs congener patterns varied among species. The patterns of PCDD/Fs in the eggs may be influenced by feeding habits, specific elimination, and metabolism. In general, concentrations of PCDDs were higher than those of PCDFs in avian eggs. On basis of lipid weight, total 2,3,7,8-TCDD toxic equivalents (TEQs) calculated based on the WHO TEFs for birds ranged from 2.04 to $42.0 \mathrm{pg} \mathrm{g}^{-1}$; and on basis of wet weight, total WHO-TEQs ranged from 0.19 to $1.59 \mathrm{pg} \mathrm{g}^{-1}$. 2,3,7,8-TCDF, 2,3,4,7,8-PeCDF, 2,3,7,8-TCDD, 1,2,3,7,8-PeCDD were the major contributors to TEQ concentration in most avian eggs, whereas 1,2,3,4,7,8-HxCDD also accounted for a major portion of TEQs in eggs of azure-winged magpie. Values of TEQs in avian eggs were lower than toxic threshold values, implying risk reduction and natural restoration of PCDD/Fs contamination in Dongting Lake region.
\end{abstract}

(c) 2007 Elsevier Ltd. All rights reserved.

Keywords: Avian eggs; Dongting Lake; Dioxins; Risk assessment

\section{Introduction}

Dongting Lake located in Hunan Province of China is the second-largest freshwater lake in China. The total area of the lake is about $2625 \mathrm{~km}^{2}$. Dongting Lake is an important source of grain and freshwater fish in China and is also an endemic region of schistosomiasis. Oncomelania hupensis gredler is the only lodging host of schistosome and plays a vital role in schistosomiasis spread. To kill oncomelania hupensis gredler, large amounts of sodium pentachlorophenate (Na-PCP) which was found containing polychlorinated dibenzo- $p$-dioxins and dibenzofurans (PCDD/Fs)

\footnotetext{
${ }^{*}$ Corresponding author. Tel.: +86 106284 9172; fax: +86 1062923563 . E-mail address: zhengmh@rcees.ac.cn (M. Zheng).
}

impurities had been sprayed for over 30 years (Ding et al., 1990; Bao et al., 1995). Being highly lipophilic and resistant towards metabolic breakdown, PCDD/Fs can accumulate in predators at the top of a food chain (Braune and Simon, 2003), causing potential risk to high trophic level wildlife (Koistinen et al., 1995; Kumar et al., 2001, 2002; Kang et al., 2002).

Previous reports indicated that PCDD/Fs were closely associated with incidences of bird deformities and mortality (Elliott et al., 1996a,b; Loonen et al., 1996; Elliott and Norstrom, 1998; Olsson et al., 2000; Hilscherova et al., 2003; Malisch and Baum, 2004; Tanabe et al., 2004). These highly lipophilic compounds are likely to be transferred into eggs during the mobilization of female lipid and have been established as endocrine/hormone disrupters in birds. High correlation has been observed with deformity/ 
anatomical malformations and egg concentrations of PCDD/Fs. Therefore, avian eggs are frequently used to monitor the contamination of the environment with xenobiotic substances to evaluate exposure risk in a multitude of avian species (Wiesmüller et al., 1999, 2002; Custer et al., 2002; Connell et al., 2003).

Although Na-PCP had been prohibited sprayed in the Dongting Lake region since 1996, recent studies showed that sediment, soil and breast milk from the district were contaminated with PCDD/Fs (Zheng et al., 1997, 2003a,b; Gao et al., 2005). Therefore, congener specific accumulation of PCDD/Fs in eggs of eight avian species was determined in this study. Toxic equivalencies (TEQs) were calculated using toxic equivalency factors (TEFs) for birds reported by Van den Berg et al. (1998). The calculated TEQs were compared with those of the threshold values reported in earlier studies to conduct a risk assessment in Dongting Lake region.

\section{Materials and methods}

\subsection{Sample collection}

The eggs of eight avian species were collected from Southern Dongting Lake Nature Reserve between the spring and autumn, 2004. The collecting of avian eggs is strictly restricted by Nature Reserve Management Office at Dongting Lake. Before egg collection began, the appropriate permits were obtained. The collection of egg samples from avian species was based solely on the opportunities for survey team members to locate the nests of these species. One egg from each nest of the avian species identified was collected. The location of sampling eggs was given in Fig. 1.

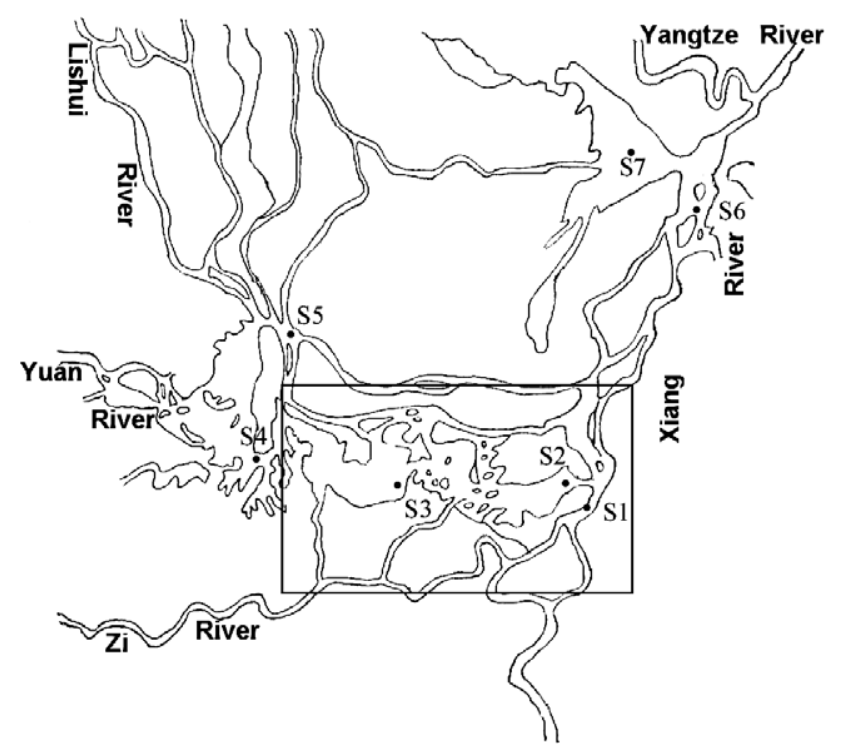

Fig. 1. Sampling sites of avian eggs and sediments from Dongting Lake region. Rectangle indicates the avian eggs collecting location; S1-S7 are the sediment sampling sites.
After washing the surface of the eggshells with an ordinary detergent and acetone and weighing all the samples, the ingredients were transferred individually to glass bottles and were sealed and stored frozen at $-20{ }^{\circ} \mathrm{C}$ until analysis. This method of storage has been shown to avoid changes in contaminant and moisture content over time. The samples were eggs of spot-billed duck (Anas poecilorhyncha), northern pintail (Anas acuta), mallard (Anas platyrhynchos), bean goose (Anser fabalis), azure-winged magpie (Cyanopica cyana), little kingfisher (Alcedo pusilla), lesser pied kingfisher (Ceryle rudis), and great egret (Ardea alba). Details of egg samples were listed in Table 1.

\subsection{Lipid determination and PCDD/Fs analysis}

Eggs were thawed at room temperature and then homogenized for PCDD/Fs analysis. One egg sample containing either one or more eggs depending on the size of the eggs to make a pool sample was analyzed for PCDD/Fs. After homogenization, eggs were freeze-dried, ground and mixed with anhydrous sodium sulfate $\left(\mathrm{Na}_{2} \mathrm{SO}_{4}\right)$. The $\mathrm{PCDD} / \mathrm{Fs}$ analysis was performed using the isotope dilution technique based on US EPA Method 1613B. Before extraction, samples were spiked with a mixture containing $15{ }^{13} \mathrm{C}_{12}$ labeled 2,3,7,8-substituted PCDD/F internal standards (Wellington Laboratories, Canada) as defined in US EPA Method 1613B. Extraction was carried out by Soxhlet extraction using $250 \mathrm{ml} n$-hexane/dichloromethane (1:1) for $24 \mathrm{~h}$. The extracts were reduced by rotary evaporation, then dried with a stream of nitrogen. Lipid contents were calculated with residues of the extracts. The lipids were dissolved with $n$-hexane and subjected to sulfuric acid wash. The eluates were reduced by rotary evaporation, and a multi-step cleanup was performed with adsorption chromatography. A multilayer silica column (from top to bottom: anhydrous sodium sulfate, $1 \mathrm{~g}$ silica-gel, $10 \mathrm{~g} \mathrm{44 \%} \mathrm{silica-}$ gel-sulfuric acid, $1 \mathrm{~g}$ silica-gel, $5 \mathrm{~g} \mathrm{33 \%}$ silica-gel-sodium hydroxide, $1 \mathrm{~g}$ silica-gel, $2 \mathrm{~g} 10 \% \mathrm{AgNO}_{3}$ silica-gel, $1 \mathrm{~g}$ silica-gel) was used and eluted with $100 \mathrm{ml} n$-hexane. The hexane extracts were further concentrated and passed through basic alumina column for further purification. Samples were then eluted with $100 \mathrm{ml} \mathrm{5 \%}$ dichloromethane/hexane and then eluted with $50 \mathrm{ml} \mathrm{50 \%}$ dichloromethane/hexane, the $50 \%$ dichloromethane/hexane elutes were concentrated to about $20 \mu \mathrm{l}$ by a stream of nitrogen. Prior to injection, a ${ }^{13} \mathrm{C}_{12}$-labeled injection standard (containing ${ }^{13} \mathrm{C}_{12}$-labeled 1,2,3,4-TCDD and 1,2,3,7,8,9-HxCDD, Wellington Laboratories) was added for calculation of recovery.

PCDD/Fs were analyzed by an Agilent 6890 gas chromatograph coupled with Micromass Autospec Ultima high-resolution mass spectrometry by tracing the $\mathrm{M}^{+}$, $(\mathrm{M}+2)^{+}$, or the most intensive ions of the isotope cluster. $\mathrm{PCDD} / \mathrm{F}$ congeners were analyzed by a $60 \mathrm{~m} \mathrm{DB} 5 \mathrm{~ms}-\mathrm{col}-$ umn $(60 \mathrm{~m} \times 0.25 \mathrm{~mm}$ i.d. $\times 0.25 \mu \mathrm{m})$. The carrier gas was helium at $1.2 \mathrm{ml} / \mathrm{min}$. Injection volume was $1 \mu \mathrm{l}$ in splitless mode with $60 \mathrm{~s}$ splitless period. The MS was operated over 
Table 1

Details of avian eggs samples collected from Dongting Lake region, China

\begin{tabular}{|c|c|c|c|c|c|}
\hline Common name & Scientific name & $n$ & $\begin{array}{l}\text { Egg weight } \\
(\mathrm{g})\end{array}$ & Feeding habits & $\begin{array}{l}\text { Age } \\
\text { (year) }\end{array}$ \\
\hline Spot-billed duck & $\begin{array}{l}\text { Anas poecilorhyncha } \\
\text { forstrer }\end{array}$ & 3 & $46.48-59.54$ & $\begin{array}{l}\text { Omnivorous; mainly eat plants and crops, also eat spiral shell and } \\
\text { insects }\end{array}$ & 4 \\
\hline Northern pintail & Anas acuta & 4 & $35.24-48.80$ & $\begin{array}{l}\text { Omnivorous; mainly eat small fish, shrimps, shellfish or } \\
\text { hydrophytes and seeds }\end{array}$ & 3 \\
\hline $\begin{array}{l}\text { Azure-winged } \\
\text { magpie }\end{array}$ & Cyanopica cyana & 12 & $6.77-9.02$ & $\begin{array}{l}\text { Omnivorous; mainly eat insects and larva, also eating some fruit } \\
\text { and seeds }\end{array}$ & 4 \\
\hline Mallard & $\begin{array}{l}\text { Anas platyrhynchos } \\
\text { Linnaeus }\end{array}$ & 2 & $30.21-35.20$ & $\begin{array}{l}\text { Omnivorous; mainly eat weed seeds, also eat insects, mollusk and } \\
\text { worms }\end{array}$ & 3 \\
\hline Bean goose & Anser fabalis Latham & 4 & $12.05-16.35$ & Granivorous; mainly eat potatoes, corns, water chestnut & 3 \\
\hline Little kingfisher & Alcedo pusilla & 2 & $7.53-8.98$ & Piscivorous; mainly eat small fishes & 3 \\
\hline $\begin{array}{l}\text { Lesser pied } \\
\text { kingfisher }\end{array}$ & Ceryle rudis & 2 & $7.52-7.73$ & Piscivorous; mainly eat fishes & 5 \\
\hline Great egret & Ardea alba & 3 & $\mathrm{NA}^{\mathrm{a}}$ & $\begin{array}{l}\text { Piscivorous; mianly eat mollusk, crustacean, insects, small fishes, } \\
\text { shrimps, batrachia }\end{array}$ & $\mathrm{NA}^{\mathrm{a}}$ \\
\hline
\end{tabular}

${ }^{\mathrm{a}}$ Not available.

10000 resolution with EI $(38 \mathrm{eV})$, and data were obtained in the selected ion monitoring (SIM) mode.

\subsection{Quality assurance and quality control}

Instrument stability and relative response factor variance were obtained from the analysis of calibration standard solutions during each sample batch. For quality control, the retention times of the analytes in a sample had to be within $2 \mathrm{~s}$ of the retention times of the internal standards and isotope ratios of the two monitored ions for each compound within $15 \%$ of the theoretical chlorine values. The limit of detection (LOD) for PCDD/Fs in a given sample was defined by a signal to noise ratio greater than three times the average baseline variation. The recoveries of the PCDD/Fs in this study were in the range of 70 $110 \%$. Laboratory method blank was run to demonstrate freedom from contamination. The duplicate sample was analyzed in the laboratory along with the regular sample, as another quality control tool to ensure valid results. In addition, a certified reference material (CARP-2 sample) purchased from Wellington Laboratories Inc. (Canada) was analyzed, and the analysis results of $\mathrm{PCDD} / \mathrm{Fs}$ were in the scope of the reference values.

\subsection{Statistical analyses}

Statistical analyses were carried out with SPSS 12.0 for windows. Principal component analysis (PCA) is a multivariate statistical technique used to derive a few new components (principal components) as a linear combination of the original variables while attempting to preserve the statistical relationships present in the original data. In this study, inter-species variations in the $\mathrm{PCDD} / \mathrm{F}$ congener patterns were investigated using PCA on all 2,3,7,8-substituted congeners. The initial variables considered were the concentration values of the 17 toxic 2,3,7,8-substituted congeners. These values were normalized to percent of sum 2,3,7,8-substituted PCDD/Fs. Rotation was used in the PCA by the varimax method to facilitate the interpretation of the results.

\section{Results and discussion}

\subsection{Contamination levels}

The levels of PCDD/Fs in the avian eggs in this study were summarized in Table 2. To enable comparisons, all necessary data (lipid content, dry matter) were included in the table. For samples with contaminant concentrations below LOD, a value of LOD/2 was assigned for the calculation of mean concentrations and the values have been rounded.

Birds were separated into three groups according to their feed habits, namely granivores, piscivores, omnivores. The eggs of grain-eating and some omnivore species accumulated less PCDD/Fs than those of piscivores species such as eggs of less pied kingfisher and great egret. The increase of total PCDD/Fs concentrations from spot-billed duck eggs to lesser pied kingfisher eggs was consistent with their increasing tropic levels. Organic contaminants were found in higher concentrations at higher avian trophic levels (Mora, 1996; Focardi et al., 1988; Olafsdottir et al., 2001). The highest concentration of PCDD/Fs was found in eggs of lesser pied kingfisher $\left(182 \mathrm{pg} \mathrm{g}^{-1}\right.$ lipid weight), which was 17 times higher than the median concentrations in eggs of spot-billed duck ( $10.8 \mathrm{pg} \mathrm{g}^{-1}$ lipid weight). Lesser pied kingfisher, great egret and little kingfisher eat fish, crustaceans, and aquatic insects on higher trophic levels than others. Spot-billed duck, northern pintail, mallard and azure-winged magpie are omnivorous, which eat plant material as major food, and also hunt and eat insects. Seeds are typical a major component of bean goose food. The concentrations of PCDD/Fs showed considerable variability among avian species. 
Table 2

Levels of 2,3,7,8- PCDD/Fs ( $\mathrm{pg} \mathrm{g}^{-1}$, lipid weight) in avian eggs from the Dongting Lake region, China

\begin{tabular}{|c|c|c|c|c|c|c|c|c|c|c|}
\hline Congeners & $\begin{array}{l}\text { Spot-billed } \\
\text { duck }\end{array}$ & $\begin{array}{l}\text { Northern } \\
\text { pintail }\end{array}$ & Mallard & Bean goose & $\begin{array}{l}\text { Little } \\
\text { kingfisher }\end{array}$ & $\begin{array}{l}\text { Lesser pied } \\
\text { kingfisher }\end{array}$ & $\begin{array}{l}\text { Azure-winged } \\
\text { magpie }\end{array}$ & $\begin{array}{l}\text { Great } \\
\text { egret }\end{array}$ & $\begin{array}{l}\text { Sediment }{ }^{\mathrm{b}} \\
\text { (1996 year) }\end{array}$ & $\begin{array}{l}\text { Sediment }{ }^{\mathrm{c}} \\
(2004 \text { year })\end{array}$ \\
\hline$\overline{n(p)^{\mathrm{a}}}$ & $3(1)$ & $4(1)$ & $2(1)$ & $4(1)$ & 1 (2) & $1(2)$ & $4(3)$ & $1(3)$ & 7 & 7 \\
\hline Moisture (\%) & $\begin{array}{l}69.0 \\
(65.9-70.8)\end{array}$ & $\begin{array}{l}68.9 \\
(66.9-71.7)\end{array}$ & $\begin{array}{l}70.1 \\
(68.9-71.3)\end{array}$ & $\begin{array}{l}79.5 \\
(77.8-80.7)\end{array}$ & 72.5 & 87.0 & $\begin{array}{l}73.5 \\
(72.9-74.1)\end{array}$ & 80.6 & & \\
\hline Lipid (\%) & $\begin{array}{l}12.6 \\
(11.6-14.0)\end{array}$ & $\begin{array}{l}13.2 \\
(10.9-14.6)\end{array}$ & $\begin{array}{l}10.20 \\
(9.5-10.9)\end{array}$ & $\begin{array}{l}6.12 \\
(5.4-7.7)\end{array}$ & 10.1 & 3.8 & $\begin{array}{l}9.4 \\
(8.9-9.8)\end{array}$ & 5.1 & & \\
\hline $2,3,7,8-\mathrm{TCDF}$ & $\begin{array}{l}1.3 \\
(1.12-1.50)\end{array}$ & $\begin{array}{l}0.9 \\
(<0.35-1.51)\end{array}$ & $\begin{array}{l}2.9 \\
(2.73-3.02)\end{array}$ & $\begin{array}{l}1.3 \\
(<0.92-2.96)\end{array}$ & $<1.2$ & 19.0 & $\begin{array}{l}0.4 \\
(<0.5-0.6)\end{array}$ & 1.3 & $\begin{array}{l}4.7 \\
(\mathrm{ND}-11.4)\end{array}$ & $\begin{array}{l}1.3 \\
(<0.1-4.0)\end{array}$ \\
\hline 1,2,3,7,8-PeCDF & $\begin{array}{l}0.3 \\
(<0.3-0.6)\end{array}$ & $\begin{array}{l}0.2 \\
(<0.4-<0.6)\end{array}$ & $\begin{array}{l}0.8 \\
(<1.00-1.01)\end{array}$ & $\begin{array}{l}0.66 \\
(<0.28- \\
<2.90)\end{array}$ & $<1$ & 11.8 & $\begin{array}{l}0.32 \\
(<0.4-1)\end{array}$ & 1.4 & $\begin{array}{l}3.3 \\
(\mathrm{ND}-8.2)\end{array}$ & $\begin{array}{l}0.9 \\
(<0.04-5.2)\end{array}$ \\
\hline 2,3,4,7,8-PeCDF & $\begin{array}{l}0.6 \\
(0.1-0.9)\end{array}$ & $\begin{array}{l}1.5 \\
(0.9-2.2)\end{array}$ & $\begin{array}{l}1.6 \\
(1.5-1.8)\end{array}$ & $\begin{array}{l}1.48 \\
(<0.7-2.4)\end{array}$ & $<0.9$ & 10.8 & $\begin{array}{l}0.4 \\
(<0.4-0.5)\end{array}$ & 5.6 & $\begin{array}{l}2.9 \\
\text { (ND-5.8) }\end{array}$ & $\begin{array}{l}0.10 \\
(<0.04-0.2)\end{array}$ \\
\hline $1,2,3,4,7,8-\mathrm{HxCDF}$ & $\begin{array}{l}0.4 \\
(0.3-0.5)\end{array}$ & $\begin{array}{l}2.1 \\
(1.6-2.9)\end{array}$ & $\begin{array}{l}1.5 \\
(1.1-1.9)\end{array}$ & $\begin{array}{l}0.9 \\
((0.4-1.6)\end{array}$ & $<0.7$ & 6.8 & $\begin{array}{l}0.2 \\
(<0.2-<0.6)\end{array}$ & 4.7 & $\begin{array}{l}4.6 \\
(\mathrm{ND}-9.9)\end{array}$ & $\begin{array}{l}1.6 \\
(0.3-4.2)\end{array}$ \\
\hline $1,2,3,6,7,8-\mathrm{HxCDF}$ & $\begin{array}{l}0.1 \\
(0.07-0.2)\end{array}$ & $\begin{array}{l}2.9 \\
(2.2-4.0)\end{array}$ & $\begin{array}{l}1.0 \\
(0.9-1.2)\end{array}$ & $\begin{array}{l}0.8 \\
(<0.4-2.0)\end{array}$ & $<0.6$ & 6.8 & $\begin{array}{l}0.22 \\
(<0.2-0.5)\end{array}$ & 3.7 & $\begin{array}{l}3.9 \\
(\mathrm{ND}-5.6)\end{array}$ & $\begin{array}{l}1.6 \\
(0.4-3.8)\end{array}$ \\
\hline $2,3,4,6,7,8-\mathrm{HxCDF}$ & $\begin{array}{l}0.2 \\
(<0.3-0.3)\end{array}$ & $\begin{array}{l}2.6 \\
(1.8-4.0)\end{array}$ & $\begin{array}{l}1.2 \\
(<0.4-2.2)\end{array}$ & $\begin{array}{l}1.4 \\
(<0.5-3.2)\end{array}$ & $<0.7$ & 4.7 & $\begin{array}{l}0.24 \\
(<0.4<0.6)\end{array}$ & 3.7 & $\begin{array}{l}1.1 \\
\text { (ND-5.9) }\end{array}$ & $\begin{array}{l}0.9 \\
(0.3-2.0)\end{array}$ \\
\hline $1,2,3,7,8,9-\mathrm{HxCDF}$ & $0.2(<0.2-0.3)$ & $0.3(1.8-3.7)$ & $\begin{array}{l}1.0(<0.7- \\
<3.1)\end{array}$ & $\begin{array}{l}0.8(<0.6- \\
2.4)\end{array}$ & $<0.8$ & $<1.2$ & $0.4(<0.4-<1.0)$ & 0.7 & ND & $\begin{array}{l}0.7(<0.04 \\
1.3)\end{array}$ \\
\hline 1,2,3,4,6,7,8-HpCDF & $\begin{array}{l}0.2 \\
(0.1-0.2)\end{array}$ & $\begin{array}{l}7.2 \\
(<0.4-<0.8)\end{array}$ & $\begin{array}{l}6.4 \\
(0.6-12.1)\end{array}$ & $\begin{array}{l}1.1 \\
(<1.0-2.0)\end{array}$ & 2.7 & 2.6 & $\begin{array}{l}0.6 \\
(0.3-1.0)\end{array}$ & 7.2 & $\begin{array}{l}132.2 \\
(\mathrm{ND}-488.6)\end{array}$ & $\begin{array}{l}7.4 \\
(3.1-14)\end{array}$ \\
\hline 1,2,3,4,7,8,9-HpCDF & $\begin{array}{l}0.1 \\
(<0.1-0.3)\end{array}$ & $\begin{array}{l}1.0 \\
(4.4-12.0)\end{array}$ & $\begin{array}{l}0.2 \\
(<0.1-<0.6)\end{array}$ & $\begin{array}{l}0.6 \\
(<0.6-<2.6)\end{array}$ & $<0.9$ & $<1.4$ & $\begin{array}{l}0.2 \\
(<0.3-<0.6)\end{array}$ & 1.5 & $\begin{array}{l}79.3 \\
(\mathrm{ND}-402.8)\end{array}$ & $\begin{array}{l}0.3 \\
(<0.05-0.9)\end{array}$ \\
\hline OCDF & $\begin{array}{l}0.4 \\
(0.2-0.6)\end{array}$ & $\begin{array}{l}11.3 \\
(6.0-22.0)\end{array}$ & $\begin{array}{l}5.1 \\
(2.0-8.2)\end{array}$ & $\begin{array}{l}0.9 \\
(<1.1-1.2)\end{array}$ & 2.0 & $<3.0$ & $\begin{array}{l}0.3 \\
(<0.4-0.5)\end{array}$ & 3.1 & $\begin{array}{l}4217 \\
(\mathrm{ND}-14610)\end{array}$ & $\begin{array}{l}32.5 \\
(11-54)\end{array}$ \\
\hline 2,3,7,8-TCDD & $\begin{array}{l}0.2 \\
(<0.2-0.4)\end{array}$ & $\begin{array}{l}0.2 \\
(<0.2-<0.4)\end{array}$ & $\begin{array}{l}0.4 \\
(<0.7-<0.8)\end{array}$ & $\begin{array}{l}0.8 \\
(<0.80-<3.8)\end{array}$ & $<0.7$ & 1.3 & $\begin{array}{l}0.5 \\
(<0.4-<1.6)\end{array}$ & 1.25 & $\begin{array}{l}94.5 \\
(4.7-624)\end{array}$ & $\begin{array}{l}0.14 \\
(<0.06-0.2)\end{array}$ \\
\hline 1,2,3,7,8-PeCDD & $\begin{array}{l}0.3 \\
(0.3-0.4)\end{array}$ & $\begin{array}{l}0.3 \\
(<0.5-<0.6)\end{array}$ & $\begin{array}{l}0.4 \\
(0.2-1.4)\end{array}$ & $\begin{array}{l}1.2 \\
(<0.9-2.2)\end{array}$ & $<1.1$ & 6.6 & $\begin{array}{l}0.6 \\
(<0.4<1.7)\end{array}$ & 6.03 & $\begin{array}{l}76 \\
(24-183)\end{array}$ & $\begin{array}{l}0.10 \\
(0.06-0.2)\end{array}$ \\
\hline 1,2,3,4,7,8-HxCDD & $\begin{array}{l}0.7 \\
(0.7-0.8)\end{array}$ & $\begin{array}{l}0.5 \\
(0.2-1.5)\end{array}$ & $\begin{array}{l}0.9 \\
(<0.4-1.6)\end{array}$ & $\begin{array}{l}1.43 \\
(<0.5-2.2)\end{array}$ & 25.6 & 15.0 & $\begin{array}{l}0.3 \\
(<0.3-0.6)\end{array}$ & 20.2 & $\begin{array}{l}91 \\
(15-215)\end{array}$ & $\begin{array}{l}5.59 \\
(0.6-12)\end{array}$ \\
\hline 1,2,3,6,7,8-HxCDD & $\begin{array}{l}0.2 \\
(0.2-0.3)\end{array}$ & $\begin{array}{l}0.4 \\
(0.3-0.5)\end{array}$ & $\begin{array}{l}0.2 \\
(<0.2-<0.4)\end{array}$ & $\begin{array}{l}0.5 \\
(<0.5-0.7)\end{array}$ & $<0.6$ & 5.5 & $\begin{array}{l}0.3 \\
(<0.3-0.3)\end{array}$ & 1.2 & $\begin{array}{l}14 \\
(\mathrm{ND}-79.5)\end{array}$ & $\begin{array}{l}1.46 \\
(0.2-2.9)\end{array}$ \\
\hline 1,2,3,7,8,9-HxCDD & $\begin{array}{l}0.2 \\
(0.2-0.4)\end{array}$ & $\begin{array}{l}0.14 \\
(<0.19-0.29)\end{array}$ & $\begin{array}{l}0.33 \\
(<0.44-<0.89)\end{array}$ & $\begin{array}{l}0.43 \\
(<0.59- \\
<1.48)\end{array}$ & $<0.62$ & 3.95 & $\begin{array}{l}0.2 \\
(<0.2-0.4)\end{array}$ & 5.8 & $\begin{array}{l}4.6 \\
\text { (ND-27.3) }\end{array}$ & $\begin{array}{l}4.94 \\
(0.7-9.1)\end{array}$ \\
\hline 1,2,3,4,6,7,8-HpCDD & $\begin{array}{l}0.3 \\
(<0.3-0.5)\end{array}$ & $\begin{array}{l}2.9 \\
(1.2-3.8)\end{array}$ & $\begin{array}{l}4.3 \\
(<0.6-5.7)\end{array}$ & $\begin{array}{l}6.7 \\
(0.8-15.1)\end{array}$ & 8.3 & 16.1 & $\begin{array}{l}3.2 \\
(0.6-4.9)\end{array}$ & 43.0 & $\begin{array}{l}587.6 \\
(103.6-2506)\end{array}$ & $\begin{array}{l}52.5 \\
(2.6-109)\end{array}$ \\
\hline OCDD & $\begin{array}{l}5.1 \\
(3.8-6.6)\end{array}$ & $\begin{array}{l}28.0 \\
(18.6-49.3)\end{array}$ & $\begin{array}{l}14.8 \\
(12.2-17.3)\end{array}$ & $\begin{array}{l}28.0 \\
(7.86-57.9)\end{array}$ & 45.9 & 67.9 & $\begin{array}{l}11.3 \\
(5.4-21.2)\end{array}$ & 35.6 & $\begin{array}{l}116320 \\
(48349- \\
218527)\end{array}$ & $\begin{array}{l}2498 \\
(100-5113)\end{array}$ \\
\hline
\end{tabular}

$\sum \mathrm{PCDD} / \mathrm{Fs}$$$
136
$$

147

223

65.1

4123 


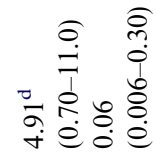

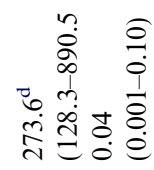

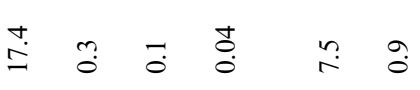

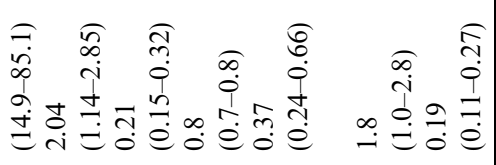

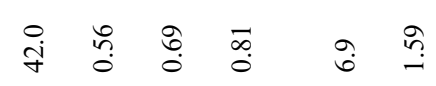

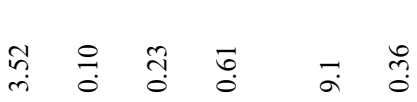

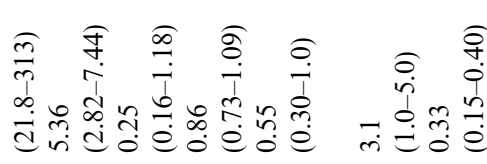

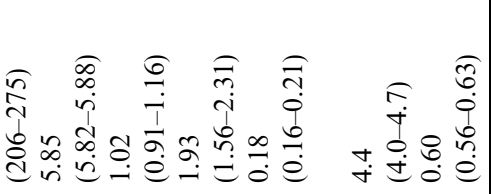

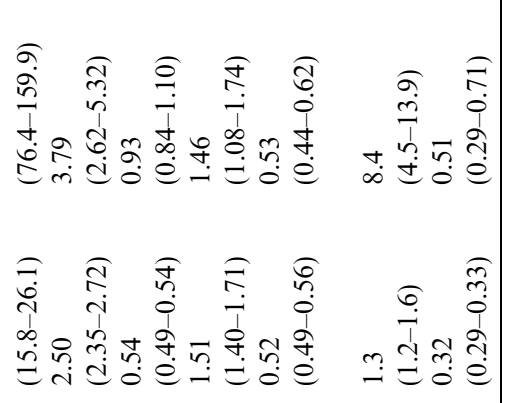

Among all the analyzed specimens, total PCDD/Fs concentration of great egret eggs was the highest, mainly consisting of non-2,3,7,8-substituted PCDD/Fs. In addition, the proportion of non-2,3,7,8-substituted compounds to total $\mathrm{PCDD} / \mathrm{Fs}$ concentrations in eggs of great egret was $96 \%$, whereas percent of non-2,3,7,8substituted compounds accounting to total PCDD/Fs concentrations were $48 \%$ in spot-billed duck eggs, $46 \%$ in northern pintail eggs, $82 \%$ in mallard eggs, $70 \%$ in bean goose eggs, $39 \%$ in azure-winged magpie eggs, $18 \%$ in little kingfisher eggs and 63\% lesser pied kingfisher eggs, respectively.

\subsection{PCA results and PCDD/Fs congener profiles}

To evaluate similarities or differences of PCDD/Fs congener patterns in each sample, all data were normalized to percent of sum 2,3,7,8-substituted PCDD/Fs. Principal components (PCs) were extracted using PCA on the percentages of 17 toxic 2,3,7,8-substituted PCDD/Fs in the avian egg samples. In this study, the PCs were obtained by their eigenvalues over 1. By processing, two PCs were extracted which could explain $90.9 \%$ of the data variance. The loading plot (Fig. 2) and score plot (Fig. 3) after varimax rotation were obtained. The loading plot showed that a principal component (PC1) accounted for $58.2 \%$ of the variance and was characterized by OCDD. The second PC (PC2) accounted for $32.7 \%$ of the total variance and was loaded most positively by the $1,2,3,4,6,7,8-\mathrm{HpCDD}$ and 1,2,3,4,7,8-HxCDD congeners and loaded most negatively by the OCDF and 2,3,4,6,7,8-HxCDF congeners. It can be observed from Fig. 3, all avian egg samples scored positively on PC1 (indicating importance of OCDD congener) and all positively on PC2 (indicating the importance of 1,2,3,4,6,7,8-HpCDD and 1,2,3,4,7,8-HxCDD congeners). The PCA results indicated that the composition of PCDD/Fs in eggs of great egret was generally different from others. In fact, the limited number of piscivorous avian eggs does not allow comprehensive statistical interpretation. The results were likely due to different bioaccumulation and uptake associated with different environmental sources. A relatively clear clustering of avian eggs except great egret eggs was observed, showing that OCDD was the dominant contaminant in these species.

Historically, the concentrations of PCDD/Fs in the sediments of Dongting Lake region were high, but the levels of PCDD/Fs declined dramatically due to the dilution effect of several serious floods since 1996 (Zheng et al., 1997, 2003b; Gao et al., 2005). Levels of PCDD/Fs in sediments taken in 1996 and 2004 were showed in Table 2. It can be seen from Table 2, OCDD, 1,2,3,4,6,7,8-HpCDD and OCDF were major congeners of PCDD/Fs in sediments. In this study, the similarity among and isomeric patterns suggested that the primary exposure source to PCDD/Fs of avian eggs was correlated with spraying of Na-PCP. 


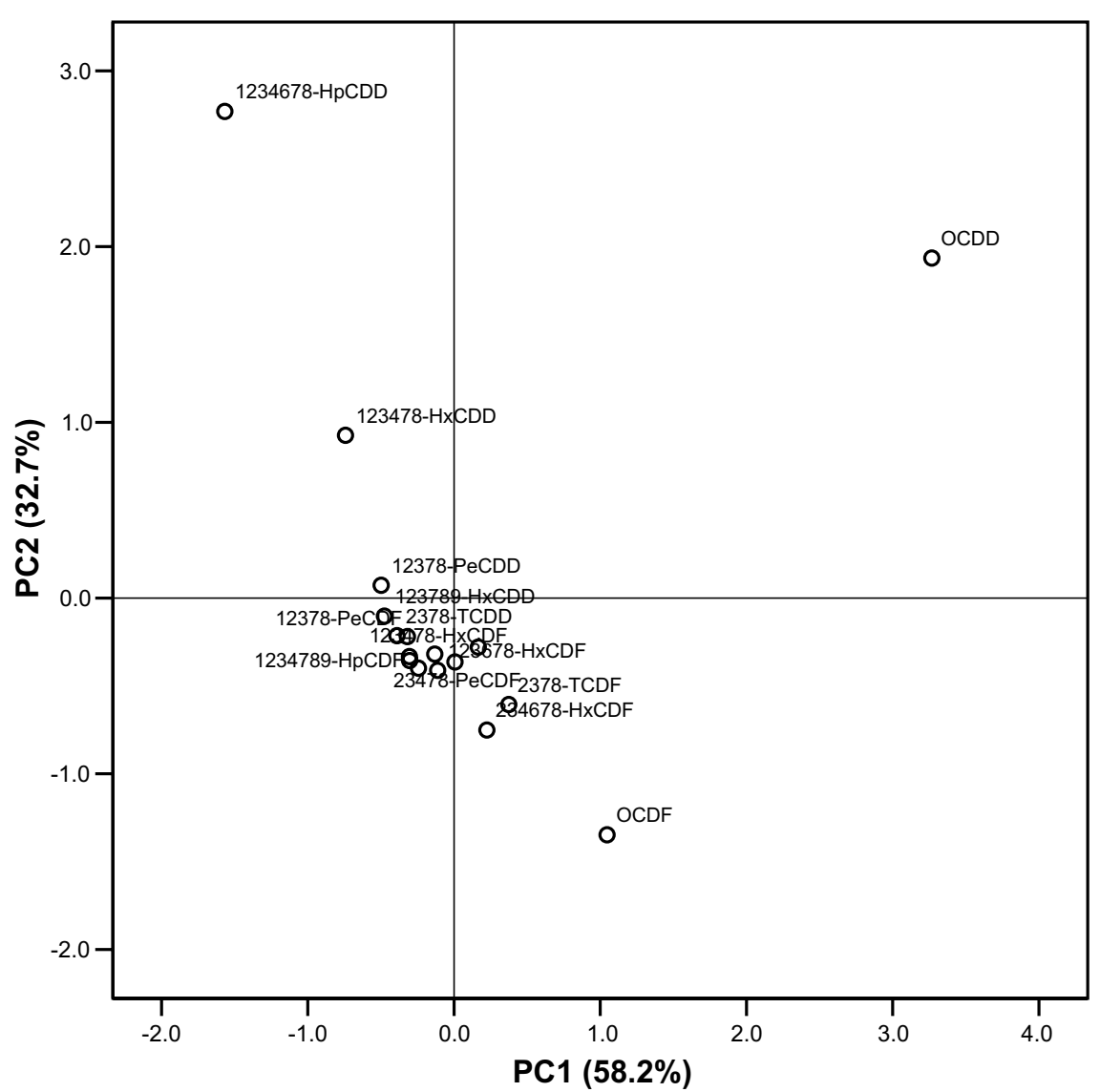

Fig. 2. Loading plot of PCA based on the percentages of 17 2,3,7,8-substituted PCDD/Fs for avian eggs from Dongting Lake region, China.

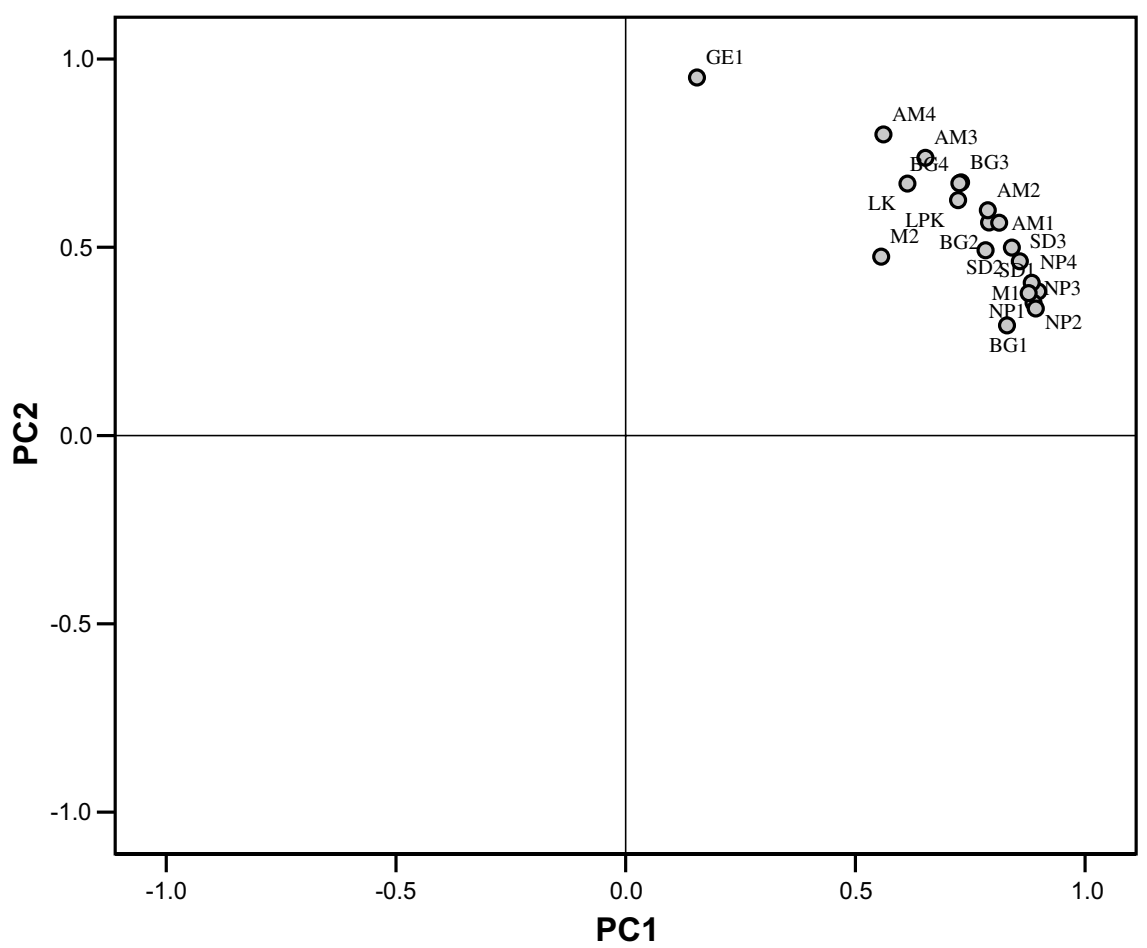

Fig. 3. Score plot of PCA based on the percentages of 2,3,7,8-substituted PCDD/Fs for avian eggs from Dongting Lake region, China. SD: spot-billed duck; NP: Northern pintail; AM: Azure-winged magpie; M: Mallard; BG: Bean goose; LK: Little kingfisher; LPK: Lesser pied kingfisher; GE: Great egret. 
Choi et al. (2001a) reported 1,2,3,7,8-PeCDD, 1,2,3,6,7,8HxCDD, 2,3,4,7,8-PeCDF and 1,2,3,6,7,8-HxCDF were the major congeners of PCDD/Fs in birds identified. In addition, 1,2,3,7,8-PeCDD and 2,3,4,7,8-PeCDF were often reported as major congeners in bird tissues (Kannan et al., 2001; Choi et al., 2001b; Senthilkumar et al., 2002; Braune and Simon, 2003; Tanabe et al., 2004). The patterns of accumulation were related to the biology availability of PCDD/ Fs congeners. Previous investigations suggested that a molecular cross-section $>0.95 \mathrm{~nm}$ for the PCDD/Fs be less efficiently taken up by organisms (Opperhuizen et al., 1985). The molecular cross-sectional size of most of the higher chlorinated compounds is above $0.95 \mathrm{~nm}$. However, in this study, concentrations of highly chlorinated PCDD/ Fs congeners were higher than lowly chlorinated ones owing to the contamination originated from Na-PCP.

Relatively higher levels of PCDDs than that of PCDFs were found in eggs of spot-billed duck, bean goose, little kingfisher, lesser pied kingfisher, azure-winged magpie and great egret. Previous study also reported PCDD congeners were predominant in liver of spot-billed duck (Senthilkumar et al., 2002). There are two possible explanations: (1) birds exposed to higher concentrations of PCDDs than PCDFs originated from using Na-PCP, and (2) metabolic or elimination capacity of PCDFs was higher than that of PCDDs. Ratios of PCDDs to PCDFs were about equal to 1 in eggs of northern pintail and mallard, suggesting the two species have higher metabolic and elimination capacity of PCDDs. The implication of feeding habits and differences in metabolic capacity of avian species were important for the variation in congener patterns.

\subsection{Toxic equivalents (TEQs) concentrations and toxicity contribution}

In the WHO TEF model for birds, the toxicities of 2,3,7,8-TCDF, 1,2,3,7,8-PeCDD, and 2,3,4,7,8-PeCDF were reevaluated and the TEFs for these congeners are 1.0, which implied that the toxicity of these congeners are the same as that of 2,3,7,8-TCDD. These four congeners dominated the TEQs and were responsible for almost $90 \%$ of the TEQs of PCDD/Fs in different avian eggs (Fig. 4).

The contribution of PCDD and PCDF congeners to their corresponding TEQs varied among species. On basis of wet weight, concentrations of TEQs in avian eggs ranged from $1.59 \mathrm{pg} \mathrm{g}^{-1}$ in lesser pied kingfisher to $0.19 \mathrm{pg} \mathrm{g}^{-1}$ in azure-winged magpie (Table 2). On basis of lipid weight, total WHO-TEQ values ranged from 42.0 (lesser pied kingfisher) to $2.04 \mathrm{pg} \mathrm{g}^{-1}$ (azure-winged magpie).

For eggs of spot-billed duck, northern pintail and mallard, 2,3,7,8-TCDF and 2,3,4,7,8-PeCDF were major contributors to TEQs, accounting for $54.6 \%$ and $28.1 \%$, respectively. For eggs of bean goose, lesser pied kingfisher, azure-winged magpie and great egret, 2,3,7,8-TCDF, 2,3, 4,7,8-PeCDF, 1,2,3,7,8-PeCDD were major contributors to TEQs. $1,2,3,6,7,8$-HxCDD, 2,3,7,8-TCDF, $1,2,3,7,8-$ PeCDD, 2,3,4,7,8-PeCDF were major contributors to TEQs for eggs of little kingfisher. This maybe related to differences of edible habits.

\subsection{Global comparison}

Table 3 summarized the concentrations of PCDD/Fs in avian eggs from other parts of the world in recent literatures. Concentrations of $\mathrm{PCDD} / \mathrm{Fs}$ analyzed in eggs of piscivorous avian species in this study were higher than those observed in black-tailed gull eggs from Rishiri Island, Japan (Choi et al., 2001b). The observed mean PCDDs and PCDFs concentrations in avian eggs analyzed in this study were lower than those from Prince Leopold Island, Canada (Braune and Simon, 2003), Japan (Kumar et al., 2005), Brandenburg, Germany (Wiesmüller et al., 2002), and Ya-Er Lake, China (Wu et al., 2001).

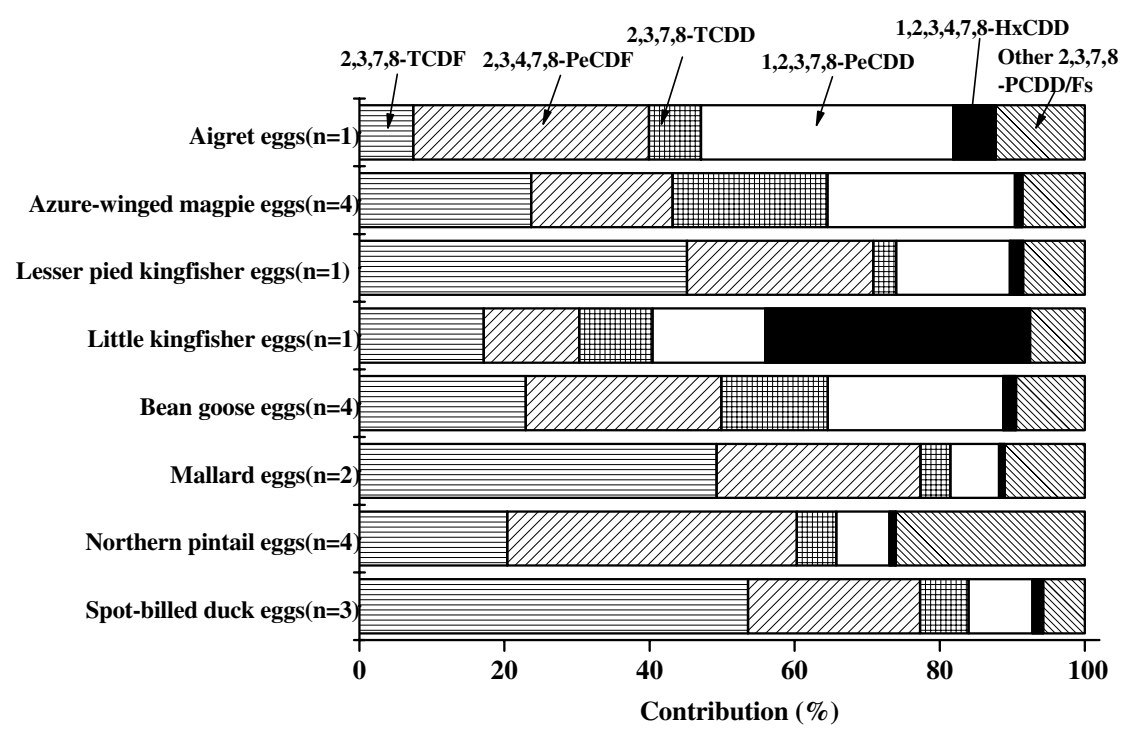

Fig. 4. Contribution of individual PCDD/F congener to TEQs in avian eggs. 
Table 3

Comparison of PCDD/Fs in avian eggs from other parts of the world

\begin{tabular}{|c|c|c|c|c|c|c|c|c|}
\hline Location & Species & Year & $n$ & $\begin{array}{l}\text { Lipid } \\
(\%)\end{array}$ & $\begin{array}{l}\sum_{\text {(pg g }} 2,3,7,8-\text { PCDDs } \\
\text { lipid weight })\end{array}$ & $\begin{array}{l}\sum 2,3,7,8-\text { PCDFs } \\
\left(\text { pg g }^{-1} \text { lipid weight }\right)\end{array}$ & $\begin{array}{l}\sum \text { WHO - TEQ } \\
\left(\operatorname{pg~g}^{-1} \text { lipid weight }\right)\end{array}$ & Reference \\
\hline Prince Leopold Island, Canada & $\begin{array}{l}\text { Black-legged } \\
\text { kittiwake }\end{array}$ & 1993 & $2^{\mathrm{a}}$ & 5.1 & 192 & 875 & 806 & $\begin{array}{l}\text { Braune and Simon } \\
(2003)\end{array}$ \\
\hline Prince Leopold Island, Canada & Northern fulmar & 1993 & $3^{\mathrm{a}}$ & 8.9 & 241 & 653 & 566 & $\begin{array}{l}\text { Braune and Simon } \\
(2003)\end{array}$ \\
\hline Prince Leopold Island, Canada & Thick-billed murre & 1993 & $3^{\mathrm{a}}$ & 6.8 & 65 & 207 & 154 & $\begin{array}{l}\text { Braune and Simon } \\
(2003)\end{array}$ \\
\hline Rishiri Island, Japan & Black-tailed gulls & 1998 & 10 & $\mathrm{NA}^{\mathrm{b}}$ & $28.4(9.80-84.5)$ & $24.5(13.1-35.7)$ & $381.7(194-584)^{\mathrm{c}}$ & Choi et al. (2001b) \\
\hline Dongting Lake, China & Piscivores & 2004 & 3 & $\begin{array}{l}3.8- \\
10.1\end{array}$ & $103(81.3-116)$ & $35.4(8.0-65.4)$ & $21.0(3.52-42.0)$ & In this study \\
\hline Dongting Lake, China & $\begin{array}{l}\text { Granivores/ } \\
\text { omnivores }\end{array}$ & 2004 & 17 & $\begin{array}{l}5.4 \\
14.6\end{array}$ & $24.4(5.7-83.3)$ & $13.3(2.4-45.3)$ & $3.76(1.14-7.44)$ & In this study \\
\hline Sagami River, Kanagawa Prefecture, Japan & $\begin{array}{l}\text { Common } \\
\text { cormorants }\end{array}$ & 2000 & 10 & $\begin{array}{l}4.56- \\
7.97\end{array}$ & $1508(878-2477)$ & $1966(804-3220)$ & $1100(570-1900)$ & Kumar et al. (2005) \\
\hline Brandenburg, Gemany & Barn owl & $\begin{array}{l}1995- \\
1996\end{array}$ & 8 & $3.8-7.6$ & $200(72-590)$ & $260(150-390)$ & $120.9(78.9-181.4)^{\mathrm{d}}$ & $\begin{array}{l}\text { Wiesmüller et al. } \\
\text { (1999) }\end{array}$ \\
\hline Berlin-Brandenburg, Germany & Sparrowhawks & $\begin{array}{l}1991- \\
1998\end{array}$ & 3 & $\begin{array}{l}7.92- \\
11.75\end{array}$ & $621(423-946)$ & $459(417-497)$ & $478(454-522)$ & $\begin{array}{l}\text { Wiesmüller et al. } \\
(2002)\end{array}$ \\
\hline Berlin-Brandenburg, Germany & Hobbies & $\begin{array}{l}1991- \\
1998\end{array}$ & 7 & $\begin{array}{l}7.03- \\
10.86\end{array}$ & $928(664-1716)$ & $376(251-774)$ & $424(275-868)$ & $\begin{array}{l}\text { Wiesmüller et al. } \\
(2002)\end{array}$ \\
\hline Berlin-Brandenburg, Germany & Northern Goshawks & $\begin{array}{l}1991- \\
1998\end{array}$ & 16 & $\begin{array}{l}4.02- \\
8.07\end{array}$ & $451(143-1881)$ & $213(93.6-612)$ & $211(83.5-694)$ & $\begin{array}{l}\text { Wiesmüller et al. } \\
(2002)\end{array}$ \\
\hline Ya-Er Lake, China & Piscivorous bird & 1997 & 2 & $\begin{array}{l}18.9- \\
20.1\end{array}$ & $75.6(75.2-76.0)$ & $1152(1124-1179)$ & $551(537-565)^{\mathrm{d}}$ & Wu et al. (2001) \\
\hline Near La Tuque, Quebec, Canada & Common merganser & 1989 & $5^{\mathrm{a}}$ & NA & 48 & 172 & $44^{\mathrm{e}}$ & Champoux (1996) \\
\hline Near La Tuque, Quebec, Canada & Common merganser & 1991 & $2^{\mathrm{a}}$ & NA & 129.1 & 397.3 & $101.1^{\mathrm{e}}$ & Champoux (1996) \\
\hline Near La Tuque, Quebec, Canada & Hooded merganser & 1991 & 2 & NA & 49.5 & 220.1 & $59.9^{\mathrm{e}}$ & Champoux (1996) \\
\hline \multirow[t]{2}{*}{ The Strait of Georgia, BC, Canada } & $\begin{array}{l}\text { Double-crested } \\
\text { cormorant }\end{array}$ & $\begin{array}{l}1973- \\
1998\end{array}$ & - & $3.0-7.8$ & $3-74^{\mathrm{f}}$ & - & $14-268$ & Harris et al. (2003) \\
\hline & & & & & $\begin{array}{l}5-151^{\mathrm{g}} \\
7-289^{\mathrm{h}}\end{array}$ & & & \\
\hline The Strait of Georgia and Northwest Vancouver & Pelagic cormorants & $1985-$ & - & $3.7-6.8$ & $0.8-28^{\mathrm{f}}$ & - & $5-146$ & Harris et al. (2003) \\
\hline
\end{tabular}

Island, BC, Canada

\section{Coastal California}

Coastal California

Coastal California

Coastal California

Little Charity Is., Lake Huron, the Great Lakes

Scarecrow Is., Lake Huron, the Great Lakes

Taquamenon Is., Lake Superior, the Great Lakes

Little Charity Is., Lake Huron, the Great Lakes

\begin{tabular}{|c|c|c|c|c|}
\hline & & & & $\begin{array}{l}3-79^{\mathrm{g}} \\
3-300^{\mathrm{h}}\end{array}$ \\
\hline Pigeon guillemot & 1993 & $13^{\mathrm{a}}$ & 10 & 6.50 \\
\hline Rhinoceros auklet & 1993 & $10^{\mathrm{a}}$ & 13 & 3.51 \\
\hline Brandt's cormorant & 1993 & $7^{\mathrm{a}}$ & 4.5 & 15.8 \\
\hline Common murre & 1993 & $9^{\mathrm{a}}$ & 14 & 9.88 \\
\hline $\begin{array}{l}\text { Double-crested } \\
\text { cormorants }\end{array}$ & 1998 & 3 & $4-5.2$ & $62(25-94)$ \\
\hline $\begin{array}{l}\text { Double-crested } \\
\text { cormorants }\end{array}$ & 1998 & 3 & $5.6-6.5$ & $16(7.4-26)$ \\
\hline $\begin{array}{l}\text { Double-crested } \\
\text { cormorants }\end{array}$ & 1998 & 3 & $5.3-6.6$ & $26(18-37)$ \\
\hline
\end{tabular}

1.50
6.86
17.65
7.05
$48(28-76)$
$37(22-57)$
$27(20-37)$
$7.7(3.4-12)$

2.14

6.80

17.06
8.51

20.8

9.2

9.4

19.9

Kannan et al.

(2001)

Kannan et al.

(2001)

Kannan et al.

(2001)

Kannan et al.

(2001) 


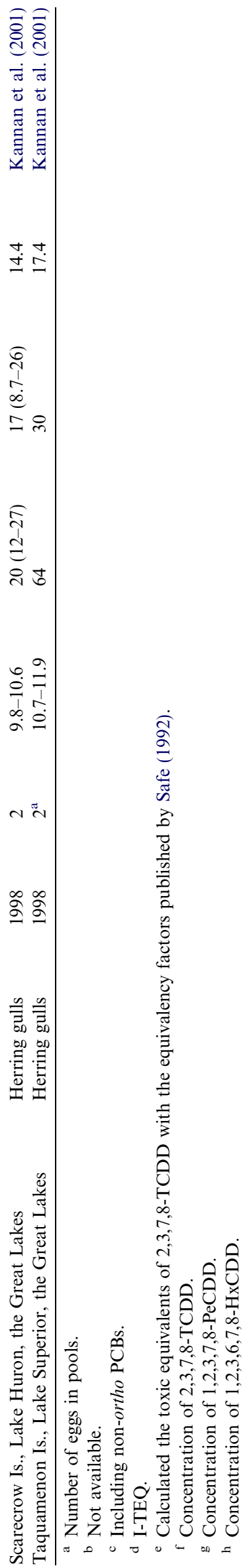

\subsection{Toxic potential or toxic risk assessments}

Toxic threshold for avian species has been reported elsewhere (Elliott et al., 1996a, 2001). Using hepatic CYP1A induction as a biomarker, a no-observedeffect-level (NOEL) of $100 \mathrm{pg} \mathrm{g}^{-1}$ and a low-observedeffect-level (LOEL) of $210 \mathrm{pg}$ WHO-TEQ $\mathrm{g}^{-1}$ on a whole egg (wet weight basis) were suggested for bald eagle chicks (Elliott et al., 1996a). Recently, Elliott et al. (2001) reported NOEL of $37 \mathrm{pg} \mathrm{g}^{-1}$ TEQs and LOEL of $130 \mathrm{pg} \mathrm{g}^{-1}$ TEQs for CYP1A on a whole egg (wet weight basis) in osprey chicks. The concentrations of TEQs in avian eggs analyzed in this study were still several orders of magnitude lower than the level associated with effects on hatching success in bald eagle and the NOEL (37 $\mathrm{pg} \mathrm{g}^{-1}$ of wet weight in eggs) and LOEL ( $130 \mathrm{pg} \mathrm{g}^{-1}$ of wet weight in eggs) suggested for osprey chicks.

These crude comparisons could not take into account the differences in biological responsiveness among different avian species. Given the relatively high thresholds for effects of PCDD/Fs, concentrations of dioxins in avian eggs probably do not significantly impact reproduction in avian species in Dongting Lake region.

\subsection{Natural restoration of dongting lake}

Dongting Lake is a flood-basin of the Yangtze River (Chang Jiang). In the July-September period, flood water from the Yangtze River flows into the lake, enlarging it greatly. The lake's area, which normally is $2625 \mathrm{~km}^{2}$, may increase to $20000 \mathrm{~km}^{2}$ in flood season, when vast amounts of water and sediment from the Yangtze River flow into the lake. In 1998, extraordinary floods occurred in the Yangtze River. The maximum peak discharge at upriver was $63300 \mathrm{~m}^{3} \mathrm{~s}^{-1}$. The water levels of Dongting Lake exceeding the historical records remained for over 40 days. Floods abated water pollution in Dongting Lake.

Na-PCP had been prohibited in Dongting lake area for 10 years. The floods maybe have a dilution effect. Levels of PCDD/Fs in sediment now were much lower than those of 1990s (Gao et al., 2005). What's more, the levels of PCDD/ Fs in avian eggs in this study were lower than those from other higher pollution areas. Using avian eggs as bioindicators, risk reduction and natural restoration of $\mathrm{PCDD} / \mathrm{Fs}$ contamination in Dongting Lake region can be observed.

\section{Acknowledgements}

This study was supported by National Natural Science Foundation of China (40332023, 20621703) and National Basic Research Program of China (2003CB415006).

\section{References}

Bao, Z.C., Wang, K.O., Kang, J.X., Zhao, L.W., 1995. Analysis of polychlorinated deibenzo- $p$-dioxins and polychlorinated dibenzofurans 
in pentachlorophenol and sodium pentachlorophenate. Chinese Environ. Chem. 14, 317-321.

Braune, B.M., Simon, M., 2003. Dioxins, furans, and non-ortho PCBs in Canadian Arctic Seabirds. Environ. Sci. Technol. 37, 3071-3077.

Champoux, L., 1996. PCBs, dioxins and furans in Hooded Merganser (Lophodytes Cucullatus), Common Merganser (Mergus Merganser) and Mink (Mustela Vison) collected along the ST. Maurice River near La Tuque, Quebec. Environ. Pollut. 92, 147-153.

Choi, J.W., Matsuda, M., Kawano, M., Min, B.Y., Wakimoto, T., $2001 \mathrm{a}$. Accumulation profiles of persistent organochlorines in water birds from an estuary in Korea. Arch. Environ. Contam. Toxicol. 41, 353363.

Choi, J.W., Matsuda, M., Kawano, M., Wakimoto, T., Iseki, N., Masunaga, S., Hayama, S.I., Watanuki, Y., 2001b. Chlorinated persistent organic pollutants in black-tailed gulls (Larus crassirostris) from Hokkaido, Japan. Chemosphere 44, 1375-1382.

Connell, D.W., Fung, C.N., Minh, T.B., Tanabe, S., Lam, P.K.S., Wong, B.F.S., Lam, M.H.W., Wong, L.C., Wu, R.S.S., Richardson, B.J., 2003. Risk to breeding success of fish-eating Ardeids due to persistent organic contaminants in Hong Kong: evidence from organochlorine compounds in eggs. Water Res. 37, 459-467.

Custer, T.W., Custer, C.M., Hines, R.H., 2002. Dioxins and congenerspecific polychlorinated biphenyls in three avian species from the Wisconsin River, Wisconsin. Environ. Pollut. 119, 323-332.

Ding, X.L., Bao, Z.C., Zhang, Z., Xu, X.B., 1990. Polychlorinated dibenzo-p-dioxins and dibenzofurans in pentachlorophenol and sodium pentachlorophenate. Chinese Environ. Chem. 9, 33-38.

Elliott, J.E., Norstrom, R.J., 1998. Chlorinated hydrocarbon contaminants and productivity of Bald Eagle population on the Pacific coast of Canada. Environ. Toxicol. Chem. 17, 1142-1153.

Elliott, J.E., Norstrom, R.J., Lorenzen, A., Hart, Kennedy, S.E., Philibert, H., Stegeman, J.J., Hart, L.E., Bellward, G.D., Cheng, K.M., 1996a. Biological effects of polychlorinated dibenzo-p-dioxins, dibenzofurans, and biphenyls in Bald Eagles (Haliaeetus leucocephalus) chicks. Environ. Toxicol. Chem. 153, 782-793.

Elliott, J.E., Wilson, L.K., Langelier, K.W., Norstrom, R.J., 1996b. Bald eagle mortality and chlorinated hydrocarbon contaminants in livers from British Columbia, Canada, 1989-1994. Environ. Pollut. 94, 9-18.

Elliott, J.E., Wilson, L.K., Henny, C.J., Trudeau, S.F., Leighton, F.A., Kennedy, S.W., Cheng, K.M., 2001. Assessment of biological effects of chlorinated hydrocarbons in Osprey chicks. Environ. Toxicol. Chem. 20, 866-879.

Focardi, S., Leonzio, C., Fossi, C., 1988. Variations in polychlorinated biphenyl congener composition in eggs of Mediterranean water birds in relation to their position in the food chain. Environ. Pollut. 52, 243-255.

Gao, L.R., Zheng, M.H., Zhang, B., Liu, W.B., Zhao, X.R., 2005. Declinging dioxins levels in the sediments from Dongting lake in China. Organohal. Comp. 67, 1085-1087.

Harris, M.L., Wilson, L.K., Norstrom, R.J., Elliott, J.E., 2003. Egg concentration of polychlorinated dibenzo- $p$-dioxins and dibenzofurans in Double-Crested (Phalacrocorax auritus) and Pelagic (P. pelagicus) Cormorants from the Strait of Georgia, Canada, 1973-1998.. Environ. Sci. Technol. 37, 822-831.

Hilscherova, K., Blankenship, A., Kannan, K., Nie, M., Williams, L.L., Coady, K., Upham, B.L., Trosko, J.E., Bursian, S., Giesy, J.P., 2003. Oxidative stress in laboratory-incubated Double-Crested Cormorant eggs collected from the Great Lakes. Arch. Environ. Contam. Toxicol. $45,533-546$.

Jarman, W.M., Sydeman, W.J., Hobson, K.A., 1997. Relationship of polychlorinated dibenzo- $p$-dioxin and polychlorinated dibenzofuran levels to stable-nitrogen isotope abundance in marine birds and mammals in coastal California. Environ. Toxicol. Chem. 16, 10101013.

Kang, Y.S., Yamamuro, M., Masunaga, S., Nakanishi, J., 2002. Specific biomagnification of polychlorinated dibenzo-p-dioxins and dibenzofurans in tufted ducks (Aythya fuligula), common cormorants (Phalacrocorax carbo) and their prey from Lake Shinji, Japan. Chemosphere $46,1373-1382$.
Kannan, K., Hilscherova, K., Imagawa, T., Yamashita, N., Williams, L.L., Giesy, J.P., 2001. Polychlorinated naphthalenes, -biphenyls, -dibenzo-p-dioxins, and -dibenzofurans in double-crested cormorants and herring gulls from Michigan water of the Great Lakes. Environ. Sci. Technol. 35, 441-447.

Koistinen, J., Koivusaari, J., Nuuja, I., Paasivirta, J., 1995. PCDEs, PCBs, PCDDs and PCDFs in Black Guillemots and White-tailed Sea Eagles from the Baltic Sea. Chemosphere 30, 1671-1684.

Kumar, K.S., Kannan, K., Paramasivan, O.N., Sundaram, V.P.S., Nakanishi, J., Masunaga, S., 2001. Polychlorinated dibenzo-p-dioxins, dibenzofurans, and polychlorinated biphenyls in human tissues, meat, fish, and wildlife samples from India. Environ. Sci. Technol. 35, 34483455.

Kumar, K.S., Kannan, K., Giesy, J.P., Masunaga, S., 2002. Distribution and elimination of polychlorinated dibenzo-p-dioxins, dibenzofurans, biphenyls, and $p, p^{\prime}$-DDE in tissues of Bald Eagles from the upper Peninsula of Michigan. Environ. Sci. Technol. 36, 2789-2796.

Kumar, K.S., Watanabe, K., Takemori, H., Iseki, N., Masunaga, S., Takasuga, T., 2005. Analysis of UNEP priority POPs using HRGCHRMS and their contamination profiles in livers and eggs of Great Cormorants (Phalacrocorax carbo) from Japan. Arch. Environ. Contam. Toxicol. 48, 538-551.

Loonen, H., Van de Guchte, C., Parsons, J.R., Voogt, P., Govers, H.A.J., 1996. Ecological hazard assessment of dioxins: hazards to organisms at different levels of aquatic food webs (fish-eating birds and mammals, fish and invertebrates). Sci. Total Environ. 182, 93-103.

Malisch, R., Baum, F., 2004. PCDD/Fs, dioxin-like PCBs and marker $\mathrm{PCBs}$ in eggs of Peregrine Falcons from Germany. Organohal. Compd. 66, 1754-1759.

Mora, M.A., 1996. Congener-specific polychlorinated biphenyl patterns in eggs of aquatic birds from the Lower Laguna Madre, Texas. Environ. Contam. Toxicol. 15, 1003-1010.

Olafsdottir, K., Petersen, A.E., Magnusdottir, E.V., Bjornsson, T., Johannesson, T., 2001. Persistent organochlorine levels in six prey species of the gyrfalcon Falco resticolus in Iceland. Environ. Pollut. $112,245-251$.

Olsson, A., Ceder, K., Bergman, A., Helander, B., 2000. Nesting blood of the white-tailed sea eagle (Haliaeetus albicilla) as an indicator of territorial exposure to organohalogen compounds - an evaluation. Environ. Sci. Technol. 34, 2733-2740.

Opperhuizen, A., van den Velde, E.W., Gobas, F.A.P.C., Liem, D.A.K., van den Steen, J.M.D., 1985. Relationship between bioconcentration in fish and steric factors of hydrophobic chemicals. Chemosphere 14, 1871-1896.

Safe, S.H., 1992. Development, validations and limitations of toxic equivalency factors. Chemosphere 25, 61-64.

Senthilkumar, K., Iseki, N., Hayama, S., Nakanishi, J., Masunaga, S., 2002. Polychlorinated dibenzo- $p$-dioxin, dibenzofurans, and dioxinlike polychlorinated biphenyls in livers of birds from Japan. Arch. Environ. Contam. Toxicol. 42, 244-255.

Tanabe, S., Watanabe, M., Minh, T.B., Kunisue, T., Nakanishi, S., Ono, H., Tanaka, H., 2004. PCDDs, PCDFs, and coplanar PCBs in Albatross from the North Pacific and Southern Oceans: levels, patterns, and toxicological implication. Environ. Sci. Technol. 38, 403-413.

Van den Berg, M., Birnbaum, L., Bosveld, B.T.C., Brunström, B., Cook, P., Feeley, M., Giesy, J., Hanberg, A., Hasegawa, R., Kennedy, S.W., Kubiak, T., Larsen, J.C., Van Leeuwen, F.X.R., Djien Liem, A.K., Nolt, C., Peterson, R.E., Poellinger, L., Safe, S., Schrenk, D., Tillitt, D., Tysklind, M., Younes, M., Waern, F., Zacharewski, T., 1998. Toxic equivalency factors (TEFs) for PCBs, PCDDs, PCDFs for human and wildlife. Environ. Health Perspec. 106, 775-792.

Wiesmüller, T., Schlatterer, B., Wuntka, B., Schneider, R., 1999. PCDDs/ PCDFs, coplanar PCBs and PCBs in Barn Owl eggs from different areas in the State of Brandenburg, Germany. Bull. Environ. Contam. Toxicol. 63, 15-24.

Wiesmüller, T., Sömmer, P., Volland, M., Schlatterer, B., 2002. PCDDs/ PCDFs, PCBs, and Organochlorine Pesticides in eggs of Eurasian 
Sparrowhawks (Accipiter nisus), Hobbies (Falco subbuteo), and Northern Goshawks (Accipiter gentilis) collected in the area of Berlin-Brandenburg, Germany. Arch. Environ. Contam. Toxicol. 42, 486-496.

Wu, W.Z., Schramm, K.W., Kettrup, A., 2001. Bioaccumulation of polychlorinated dibenzo- $p$-dioxins and dibenzofurans in the foodweb of Ya-er Lake area, China. Water Res. 35, 1141-1148.

Zheng, M.H., Bao, Z.C., Wang, K.O., Yang, H., Xu, X.B., 1997. Polychlorinated dibenzo- $p$-dioxins and dibenzofurans in lake sedi- ments from Chinese schistosomiasis areas. Bull. Environ. Contam. Toxicol. 59, 653-656.

Zheng, M.H., Yang, L.C., Zhang, B., 2003a. Polychlorinated dibenzo-pdioxins and dibenzofurans in breast milk from Chinese schistosomiasis areas. Bull. Environ. Contam. Toxicol. 70, 189-192.

Zheng, M.H., Zhang, B., Bao, Z.C., Yang, H., Xu, X.B., 2003b. Analysis of PCDD/Fs from Sediments of Dongting Lake in China. Organohal. Compd. 62, 190-192. 